ISSN : 2303-1514 | E-ISSN : 2598-5949

\title{
PENERAPAN MODEL ROLE PLAYING UNTUK MENINGKATKAN HASIL BELAJAR SISWA PADA TEMA DAERAH TEMPAT TINGGALKU DI KELAS IV SD SWASTA ADVEN TIMBANG DELI
}

\author{
Yentin Naibaho ${ }^{1}$, Darinda Sofia Tajung ${ }^{2}$, Ester J. Simrmata ${ }^{3}$ \\ ${ }^{1,2,3}$ SD Swasta Adven Timbang Deli, Indonesia \\ 1yentinnaibaho70468@gmail.com, ${ }^{2}$ darinda_tanjung@ust.ac.id, ${ }^{3}$ ejulinda@ymail.com
}

\section{APPLYING THE ROLE PLAY MODEL TO IMPROVE STUDENTS' LEARNING OUTCOMES ON THE THEME OF DAERAH TEMPAT TINGGALKU AT CLASS IV OF SD SWASTA ADVEN TIMBANG DELI}

\begin{abstract}
ARTICLE HISTORY
ABSTRACT

Submitted:

19 September 2021

$19^{\text {th }}$ September 2021

Abstract: This study aimed to improve students' learning outcomes on the theme of "Daerah Tempat Tinggalku," the sub-theme of Bangga terhadap Daerah Tempat Tinggalku, the learning 3 and 4 at grade IV SD Swasta Adven Timbang Deli by using the Role Play model. The subjects in this study were 35 fourth-grade students, and the object of this study was students' learning outcomes and the role-play model. This type of research was Classroom Action Research. Data collection techniques used were tests and sheets. The results showed an increase in students' learning outcomes. In the pretest, it was found that the average score was 59.77, and the classical completeness level was $22.8 \%$. In the first cycle, there was an increase after using the Role Play model with an average score of 71.20 and a classical completeness level of $45.71 \%$. And after the actions taken and given posttest in cycle II, the average value increased by 81.00 and the classical completeness level of $88.57 \%$. It was obtained as many as 31 students completed their learning outcomes and four students did not complete. The results obtained show that the Role Play model improved students' learning outcomes at grade IV SD Swasta Adven Timbang Deli Medan for the 2020/2021 academic year. Based on the research, teachers are advised to use the Role Play model because it is proven to improve students' learning outcomes.
\end{abstract}

Accepted:

12 Oktober 2021

$12^{\text {th }}$ October 2021

Published:

27 Desember 2021

$27^{\text {th }}$ December 2021
Keywords: learning outcomes, role play model
Abstrak: Penelitian ini bertujuan untuk meningkatkan hasil belajar siswa pada tema daerah tempat tinggalku subtema bangga terhadap daerah tempat tinggalku pembelajran 3 dan 4 di kelas IV SD Swasta Adven Timbang Deli dengan menggunakan model Role Playing. Subjek dalam penelitian ini adalah siswa kelas IV yang berjumlah 35 orang siswa dan objek dari penelitian ini adalah hasil belajar siswa dan model Role Playing. Jenis penelitian ini adalah Penelitian Tindakan Kelas. Teknik pengumpulan data yang digunakan adalah tes dan lembar. Hasil penelitian menunjukkan adanya peningkatan hasil belajar siswa. Pada pretest diperoleh bahwa nilai rata-rata 59.77 dan tingkat ketuntasan secara klasikal sebesar 22.8\%. Pada siklus I mengalami peningkatan setelah menggunakan model Role Playing dengan nilai rata-rata 71.20 dan tingkat ketuntasan klasikal sebesar 45.71\%. Dan setelah tindakan yang dilakukan dan diberikan postest siklus II nilai rata-rata meningkat sebesar 81.00 dan tingkat ketuntasan klasikal $88.57 \%$, maka diperoleh sebanyak 31 orang siswa yang tuntas hasil belajarnya dan empat orang siswa yang tidak tuntas. Dari hasil yang diperoleh dapat disimpulkan bahwa model Role Playing dapat meningkatkan hasil belajar siswa di kelas IV SD Swasta Adven Timbang Deli Medan Tahun Pembelajaran 2020/2021. Berdasarkan penelitian, maka guru disarankan meggunakan model Role Playing karena terbukti dapat meningkatkan hasil belajar siswa.

Kata Kunci: hasil belajar, model role playing

\section{CITATION}

Naibaho, Y., Tanjung, D, S., \& Simarmata, E, J. (2021). Penerapan Model Role Playing Untuk Meningkatkan Hasil Belajar Siswa Pada Tema Daerah Tempat Tinggalku Di Kelas IV SD Swasta Adven Timbang Deli. Primary: Jurnal Pendidikan Guru Sekolah Dasar, 10 (6), 14711481. DOI:http://dx.doi.org/10.33578/jpfkip.v10i6.8549. 


\section{PENDAHULUAN}

Pendidikan merupakan salah satu alat yang sangat penting bagi kehidupan manusia untuk mengembangkan pengetahuan dan ilmu yang ada dalam dirinya, sehinga mampu menjadi manusia yang berkualitas dan bersosialisasi serta mampu bersaing. Melalui pendidikan manusia dapat mengembangkan pola berpikirnya. Pendidikan juga dapat berlangsung di sekolah, dirumah dan di lingkungan masyarat.

Salah satu tujuan Pendidikan menurut Chalijah (Tanjung, 2016: 70) menyatakan bahwa "Tujuan pendidikan untuk menghantarkan manusia menuju alam kedewasaan yang sempurna lewat proses yang direncanakan dan diinginkan baik oleh dirinya maupun oleh masyarakat yang ada di sekelilingnya. Akan tetapi pendidikan di Indonesia dihadapkan pada beberapa hal diantaranya, masalah pemerataan pendidikan, masalah mutu pendidikan, masalah relevansi dan masalah efisiensi serta efektivitas".

Belajar dapat diartikan sebagai proses yang dilakukan untuk mencari informasi agar lebih banyak memahami dan mengetahui perkembangan sumber daya alam manusia dan untuk menambah pengalaman baru serta perubahan perilaku, cara berpikir, sikap dan perasaan. Dalam proses belajar mengajar di sekolah, guru berpern penting untuk mendorong, memberikan informasi baik secara tulisan maupun lisan, memberikan bimbingan dan memberikan fasilitas belajar bagi siswa agar tujuan dalam belajar dapat tercapai dengan baik.

Berdasarkan hasil obervasi yang telah dilakukan bahwa penyebab munculnya masalah tersebut adalah penerapan model-model pembelajaran dan media pembelajaran belum dilaksanakan sesuai dengan pemelajaran, Dimana guru masih menjelaskan meteri melalui buku teks saja, sehingga siswa masih kurang dilibatkan dalam pembelajaran dan masih kurang aktif. Dalam kegiatan belajar mengajar guru masih cenderung menggunakan metode ceramah. Oleh karena itu diperlukan suatu tindakan untuk memperbaiki masalah-masalah tersebut sehingga dapat meningkatkan hasil belajar siwa. Dari beberapa solusi yang ada untuk memecahkan masalah tersebut, maka diambil suatu tindakan yaitu dengan menerapkan model role playing.

Model role playing adalah suatu cara penguasaan bahan-bahan pembelajaran melalui pengembangan imajinasi dan penghayatan siswa. Pengembangan imajinasi dan penghayatan dilakukan siswa dengan memerankannya sebagai tokoh hidup atau benda mati. Permainan ini pada umumnya dilakukan lebih dari satu orang, hal itu bergantung kepada apa yang diperankan.

Role Playing atau bermain peran memiliki tiga fungsi yang secara umum berlaku dan disetujui secara sosial, yaitu memiliki nilai pendidikan, menjadi motivasi bagi anak yang diterima oleh lingkungan masyarakat dan untuk memperkuat persetujuan dari masyarakat dan begitu juga sebaliknya anak akan menerima pembelajaran dengan cara keterampilan. Role Playing berguna membatasi perilaku sehingga tidak akan mengulangi untuk kedua kalinya, bersifat mendidik, memperkuat motifasi untuk menghindarkan diri dari tingkah laku yang tidak diharapkan. Dengan demikian dapat disimpulkan bahwa pemberian role playing akan dapat memberikan pengaruh atau menumbuhkan minat dan meningkatkan hasil belajar siswa.

\section{KAJIAN TEORI}

Menurut Hamzah B.Uno (Istarani, 2019: 70) "Model ini pertama, dibuat berdasarkan asumsi bahwa sangatlah memungkinkan analogi ontetik kedalam suatu situasi permasalahan kehidupan nyata. Kedua, bahwa bermain peran dapat mendorong siswa mengekspresikan perasaannya dan bahkan melepaskan. Ketiga, bahwa proses psikologis melibatkan sikap, nilai dan keyakinan (belief) kita serta mengarahkan pada kesadaran melalui keterlibatan spontan yang disertai analisis." Sedangkan menurut Dewi Rossyta DKK (Kurnias, 2017: 3) menyakan bahwa "Model pembelajaran role playing merupakan cara penguasaan bahan-bahan pelajaran melalui pengembangan imajinasi dan penghayatan siswa terhadap materi".

Menurut Huda (2017: 115) role playing (bermain peran) merupakan sebuah model pengajaran yang berasal dari dimensi pendidikan 
individu mapun sosial. Model ini membantu masing-masing siswa untuk menemukan makna pribadi dalam dunia sosial mereka dan membatu memecahkan dilema pribadi dengan bantuan kelompok.

Menerut Hamdani (Saputra, 2015: 29) "pembelajaran role playing adalah suatu penguasaan bahan-bahan pelajaran melalui pengembangan imajinasi dan penghayatan siswa, itu dilalukan siswa dengan memerankanya sebagai tokoh hidup atau benda mati. Metode ini banyak melibatkan siswa dan membuat siswa belajar serta metode ini mempunyai nilai tambah yaitu: (1) dapat menjamin partisipasi seluruh siswa dan memberi kesempatan yang sama untuk menunjukkan kemampuannya dalam bekerja sama hingga berhasil, (2) permainan merupakan pengalaman yang menyenangkan bagi siswa.

Menurut Slameto (Aprilia, 2015: 16) "yang mendefinisikan belajar sebagai suatu proses usaha yang dilakukan seseorang untuk memperoleh suatu perubahan tingkah laku yang baru secara keseluruhan, sebagai hasil pengalamannya sendiri dalam interaksi dengan lingkungannya.

Selanjutnya menurut Sardiman (Istarani dan Intan, 2015: 1) menyatakan bahwa belajar adalah usaha merubah tingkahlaku. Berdasarkan pendapat dari parah ahlih diatas dapat disimpulkan bahwa belajar merupakan suatu proses yang dimana adanya perubahan tingkah laku, perubahan pengetahuan dan perubahan keterampilan, yang dimana seseorang itu melakukan aktivitas dalam memperoleh perubahan dalam dirinya dengan pemikkiran yang baik dan berpengalaman yang baru.

Istarani dan Pulungan (2015: 19) mendefinisikan bahwa "hasil pembelajaran adalah pernyataan yang spesifik yang dinyatakan dalam prilaku dan penampilan yang diwujudkan dalam bentuk tulisan untuk menggambarkan hasil belajar yang diharapkan. Oleh karena itu, hasil pembelajaran adalah suatu pernyataan yang jelas dan menunjukkan penampilan atau keterampilan siswa tertentu yang diharapkan dapat dicapai sebagai hasil belajar.
Menurut Depdiknas (Rizkiah, 2019: 20), "Bahwa pembelajaran tematik pada dasarnya merupakan model dari kurikulum terpadu yang menggunakan terpadu yang menggunakan tema untuk mengaitkan beberapa mata pelajaran sehingga dapat memberikan pengalaman bermakna kepada peserta didik'.

Sedangkan menurut Majid (Rizkiah, 2019: 19), "merupakan salah satu pendekatan dalam pembelajaran terpadu (Integrated Instruction) yang merupakan suatu sistem pembelajaran yang memungkinkan siswa, baik secara individual maupun kelompok, aktif menggali dan menemukan konsep serta prinsipprinsip keilmuan secara holistik bermakna dan autentik.

Menurut (Poerwandarminta, 2017: 80) pembelajaran tematik adalah pembelajaran terpadu yang menggunakan tema untuk mengaitkan beberapa mata pelajaran sehingga dapat memberikan pengalaman bermakna kepada murid.

Pembelajaran tematik merupakan salah satu model pembelajaran terpadu yang merupakan suatu sistem pembelajaran yang memungkinkan siswa, baik secara individu maupun kelompok aktif menggali dan menemukan konsep serta prinsip-prinsip keilmuan secara holistik, bermakna, dan otentik.

\section{METODE PENELITIAN}

Penelitian ini dilakukan di SD SD Swasta Adven Timbang Deli Tahun Pembelajaran 2020/2021, yang beralamat Jln. Dame No 11.A Medan Amplas Medan. Pendekatan yang digunakan dalam penelitian ini adalah pendekatan campuran. Pendekatan campuran merupakan gabungan dari pendekatan kualitatif dan pendekatan kuantitatif. Jenis penelitian yang digunakan peneliti dalam penelitian ini adalah penelitian tindakan kelas.

Rancangan dalam penelitian ini menggunakan desain model Arikunto (2016: 42) : dimana terdapat 4 tahapan yaitu perencanaan, pelaksanaan, observasi, dan refleksi. Sedangkan 
subjek dalam penelitian ini seluruh siswa kelas IV SD Swasta Adven Timbang Deli Tahun Pembelajaran 2020/2021 yang berjumlah 35 orang siswa dan peneliti juga bekerjasama dengan wali kelas yang menjadi kolaborator dalam penelitan ini sebagai observer. Dan teknik dalam pengumpumpulan data yang digunakan yaitu tes dan observasi, dengan menggunakan analisis data kualitatif dan kuantitatif.

\section{HASIL DAN PEMBAHASAN \\ Deskripsi Kondisi Awal}

Penelitian ini dilaksanakan di SD Swasta Advent Timbang Deli Medan yang terletak di jln. Dame No.11-A Timbang Deli Medan. Penelitian ini dilakukan di kelas IV SD pada tahun pembelajaran 2020/2021. Jenis penelitian yang digunakan adalah Penelitian Tindakan Kelas (PTK) dengan menggunakan Model Role Playing untuk meningkatkan hasil belajar siswa. Pada tahap awal dilakukan observasi untuk mendapatkan informasi tentang pelaksanaan pembelajaran Tema Daerah Tempat Tinggalku di kelas IV SD Swasta Advent Timbang Deli tahun pembelajaran 2020/2021. Observasi dilakukan untuk memperoleh gambaran tentang pelaksanaan proses pembelajaran dan hasil belajar siswa. Nilai mata pelajaran Tema Daerah Tempat Tinggalku tersebut masih tergolong rendah sehingga perlu dilakukan tindakan perbaikan dengan menggunakan Model Role Playing pada Tema Daerah Tempat Tinggalku.

Penelitian ini dilakukan sebanyak 2 siklus yang meliputi perencanaan, pelaksanaan, observasi, dan refleksi. Dalam pelaksanaan ini, peneliti dan guru kelas melakukan kerja sama yang mana peneliti bertindak sebagai guru dan guru bertugas untuk mengamati guru dalam proses belajar mengajar. Proses pembelajaran bertujuan untuk meningkatkan hasil belajar siswa. Faktor penting yang merupakan salah satu penentu keberhasial proses pembelajaran adalah model pembelajaran yang digunakan saat mengajarkan materi pembelajaran kepada siswa.

\section{Ketuntasan Hasil Belajar secara Individual}

Untuk mengetahui kemampuan awal siswa dan juga untuk mengetahui kesulitankesulitan yang dialami siswa dalam memahami materi yang hendak dijelaskan pada awal pertemuan terlebih dahulu peneliti memberikan pre test sebanyak 60 soal kepada siswa kelas IV SD Swasta Wesley 2 Tanjung Morawa yang berjumlah 35 orang. Rumus untuk menghitung ketuntasan individu adalah sebagai berikut:

Menggunakan rumus persamaan sebagai berikut: $\mathrm{KB}=\frac{T}{T t} \times 100 \%$

Keterangan :

$\mathrm{KB}=$ Ketuntasan Belajar

$\mathrm{T}=$ Jumlah skor yang diperoleh siswa

$\mathrm{Tt}=$ jumlah skor total

Hasil pretest menunjukkan bahwa tingkat ketuntasan belajar siswa kelas IV masih rendah. Hal ini dapat kita lihat pada tabel 1 di bawah ini.

Tabel 1. Ketuntasan Hasil Belajar Siswa secara Individu pada Pre Test

\begin{tabular}{|l|l|c|c|l|}
\hline No & Nama Siswa & Nilai KKM & Nilai Pretest & $\begin{array}{l}\text { Tuntas/Tidak } \\
\text { Tuntas }\end{array}$ \\
\hline 1 & Agung Simanjuntak & 70 & 56 & Tidak Tuntas \\
\hline 2 & Ayu Sihombing & 70 & 70 & Tuntas \\
\hline 3 & Citra Simbolon & 70 & 69 & Tidak Tuntas \\
\hline 4 & Catrin Manalu & 70 & 44 & Tidak Tuntas \\
\hline 5 & Chika & 70 & 57 & Tidak Tuntas \\
\hline 6 & Daniel Manalu & 70 & 48 & Tidak Tuntas \\
\hline 7 & Daniel sinurat & 70 & 53 & Tidak Tuntas \\
\hline 8 & Delima Marbun & 70 & 72 & Tuntas \\
\hline
\end{tabular}




\section{PRIMARY: JURNAL PENDIDIKAN GURU SEKOLAH DASAR \\ VOLUME 10 NOMOR 6 DESEMBER 2021}

ISSN : 2303-1514 | E-ISSN : 2598-5949

DOI : http://dx.doi.org/10.33578/jpfkip.v10i6.8549

https://primary.ejournal.unri.ac.id/index.php/JPFKIP

\begin{tabular}{|c|c|c|c|c|}
\hline 9 & Elisabet Sihotang & 70 & 68 & Tidak Tuntas \\
\hline 10 & Ester Sihombing & 70 & 38 & Tidak Tuntas \\
\hline 11 & Febriani Siringoringo & 70 & 47 & Tidak Tuntas \\
\hline 12 & Ferdi Munthe & 70 & 39 & Tidak Tuntas \\
\hline 13 & Farel Manalu & 70 & 58 & Tidak Tuntas \\
\hline 14 & Feberi Sijabat & 70 & 52 & Tidak Tuntas \\
\hline 15 & Frans Dika & 70 & 55 & Tidak Tuntas \\
\hline 16 & Geisha Manalu & 70 & 49 & Tidak Tuntas \\
\hline 17 & Harry Hutabarat & 70 & 76 & Tuntas \\
\hline 18 & Ines sinaga & 70 & 62 & Tidak Tuntas \\
\hline 19 & Joel Silitonga & 70 & 48 & Tidak Tuntas \\
\hline 20 & Jonatan Sibarani & 70 & 68 & Tidak Tuntas \\
\hline 21 & Kenzou Sinaga & 70 & 77 & Tuntas \\
\hline 22 & Lisbet Sigalingging & 70 & 66 & Tidak Tuntas \\
\hline 23 & Moses Lasut & 70 & 72 & Tuntas \\
\hline 24 & Nova Purba & 70 & 57 & Tidak Tuntas \\
\hline 25 & Putri Tamba & 70 & 48 & Tidak Tuntas \\
\hline 26 & Riris Simamora & 70 & 59 & Tidak Tuntas \\
\hline 27 & Rika Simanungkalit & 70 & 60 & Tidak Tuntas \\
\hline 28 & Richael Simbolon & 70 & 74 & Tuntas \\
\hline 29 & Rizky Simbolon & 70 & 58 & Tidak Tuntas \\
\hline 30 & Sinar Simbolon & 70 & 40 & Tidak Tuntas \\
\hline 31 & Selvi Tamba & 70 & 71 & Tuntas \\
\hline 32 & Tama Situmorang & 70 & 68 & Tidak tuntas \\
\hline 33 & Thyo Simbolon & 70 & 68 & Tidak tuntas \\
\hline 34 & Tiur Nainggolan & 70 & 77 & Tuntas \\
\hline 35 & Yosia Marpaung & 70 & 68 & Tidak tuntas \\
\hline & $\Sigma X$ & & \multirow{3}{*}{$\begin{array}{l}2.092 \\
59.77\end{array}$} & \\
\hline & $\mathrm{X}$ & & & \\
\hline & $\mathrm{N}$ & & & \\
\hline
\end{tabular}

Keterangan :

$\begin{array}{ll}\sum_{\mathrm{X}} \mathrm{N} & \text { : Jumlah Semua nilai Siswa } \\ & \text { : Nilai Rata-rata }\end{array}$
$\mathrm{N} \quad$ : Banyak Siswa

Ketuntasan hasil belajar siswa secara individu pada pre test dapat dilihat pada tabel berikut ini:

Tabel 2. Deskripsi Ketuntasan Individual Siswa pada Pre Test

\begin{tabular}{|c|c|c|}
\hline No & Jumlah siswa & Keterangan \\
\hline 1 & 8 siswa & Tuntas \\
\hline 2 & 27 siswa & Tidak tuntas \\
\hline
\end{tabular}

Ketuntasan hasil belajar siswa secara individu pada tindakan awal atau pretest dapat dilihat pada grafik di bawah ini: 


\section{PRIMARY: JURNAL PENDIDIKAN GURU SEKOLAH DASAR \\ VOLUME 10 NOMOR 6 DESEMBER 2021 \\ ISSN : 2303-1514 | E-ISSN : 2598-5949 \\ DOI : http://dx.doi.org/10.33578/jpfkip.v10i6.8549 \\ https://primary.ejournal.unri.ac.id/index.php/JPFKIP}

Hasil belajar individual pretest

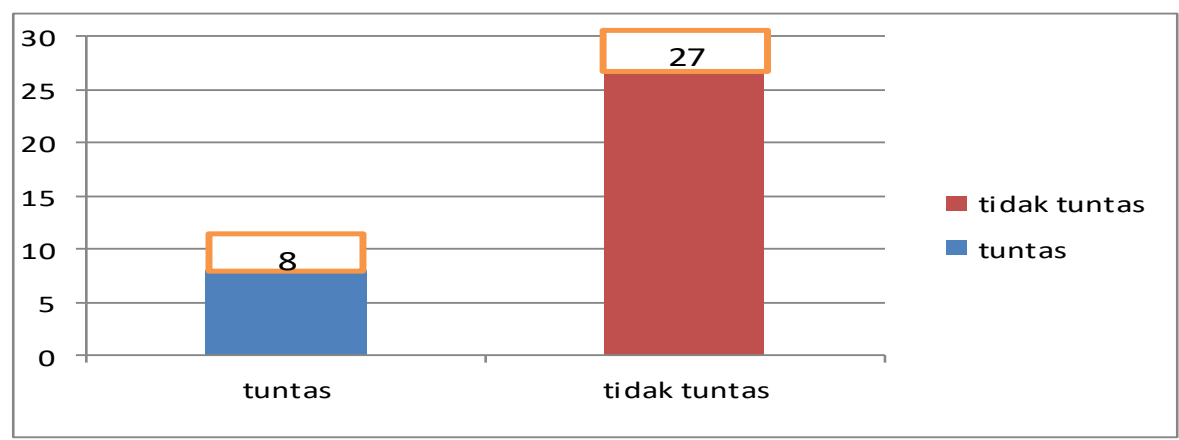

Gambar 1. Hasil belajar individual pretest

Perbandingan Hasil Tindakan Antar Siklus

Perbandingan Hasil Belajar Tindakan Antara

Siklus

Dari mulai hasil belajar atau ketuntasan

belajar mulai dari pretes, postes siklus I dan postes siklus II, terlihat adanya peningkatan yang baik dicapai siswa. Peningkatan hasil belajar siswa pada setiap siklusnya dapat dilihat pada tabel di bawah ini.

Tabel 3. Hasil Belajar Siswa Pada Pre Test, Post test siklus 1 dan Post Test Siklus II

\begin{tabular}{|l|l|l|l|l|l|}
\hline No & Nama Siswa & \multirow{2}{*}{ Pretest } & \multicolumn{2}{|l|}{ Nilai Post Test } & Tuntas/Tidak Tuntas \\
\cline { 4 - 5 } & & & Siklus I & Siklus II & \\
\hline 1 & Agung Simanjuntak & 56 & 80 & 87 & Meningkat \\
\hline 2 & Ayu Sihombing & 70 & 70 & 80 & Meningkat \\
\hline 3 & Citra Simbolon & 69 & 69 & 93 & Meningkat \\
\hline 4 & Catrin Manalu & 44 & 60 & 87 & Meningkat \\
\hline 5 & Chika & 57 & 66 & 60 & Tidak Tuntas \\
\hline 6 & Daniel Manalu & 48 & 69 & 52 & Tidak Tuntas \\
\hline 7 & Daniel Sinura & 53 & 88 & 93 & Meningkat \\
\hline 8 & Delima Marbun & 72 & 72 & 93 & Meningkat \\
\hline 9 & Elisabet Sihotang & 68 & 75 & 87 & Meningkat \\
\hline 10 & Febriani Siringoringo & 38 & 67 & 73 & Meningkat \\
\hline 11 & Ester Sihombing & 47 & 58 & 80 & Meningkat \\
\hline 12 & Ferdi Munthe & 39 & 66 & 73 & Meningkat \\
\hline 13 & Farel Manalu & 58 & 80 & 87 & Meningkat \\
\hline 14 & Febri Sijabat & 52 & 60 & 87 & Meningkat \\
\hline 15 & Frans Dika & 55 & 69 & 93 & Meningkat \\
\hline 16 & Geisha Manalu & 49 & 69 & 67 & Tidak Tuntas \\
\hline 17 & Harry Hutabarat & 76 & 80 & 90 & Meningkat \\
\hline 18 & Ines Sinaga & 62 & 73 & 92 & Meningkat \\
\hline 19 & Joel Silitonga & 48 & 68 & 72 & Meningkat \\
\hline 20 & Jonatan Sibarani & 68 & 69 & 73 & Meningkat \\
\hline & & & & & \\
\hline
\end{tabular}




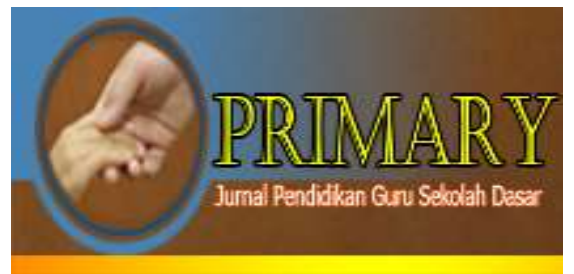

\section{PRIMARY: JURNAL PENDIDIKAN GURU SEKOLAH DASAR \\ VOLUME 10 NOMOR 6 DESEMBER 2021}

ISSN : 2303-1514 | E-ISSN : 2598-5949

DOI : http://dx.doi.org/10.33578/jpfkip.v10i6.8549

https://primary.ejournal.unri.ac.id/index.php/JPFKIP

\begin{tabular}{|l|l|l|l|l|l|}
\hline 21 & Kenzou Sinaga & 77 & 79 & 80 & Meningkat \\
\hline 22 & Lisbet Sigalingging & 66 & 65 & 85 & Meningkat \\
\hline 23 & Moses Lasut & 72 & 72 & 81 & Meningkat \\
\hline 24 & Nova Purba & 57 & 66 & 66 & Meningkat \\
\hline 25 & Putri Tamba & 48 & 69 & 79 & Meningkat \\
\hline 26 & Riris Simamora & 59 & 82 & 77 & Meningkat \\
\hline 27 & Rika Simanungkalit & 60 & 62 & 88 & Meningkat \\
\hline 28 & Richael Simbolon & 74 & 78 & 78 & Tutans \\
\hline 29 & Risky Simbolon & 58 & 79 & 72 & Tuntas \\
\hline 30 & Sinar Simbolon & 40 & 65 & 88 & Meningkat \\
\hline 31 & Selvi Tamba & 71 & 77 & 86 & Meningkat \\
\hline 32 & Tama Situmorang & 68 & 68 & 90 & Meningkat \\
\hline 33 & Thyo Simbolon & 68 & 65 & 94 & Meningkat \\
\hline 34 & Tiur Nainggolan & 77 & 77 & 82 & Meningkat \\
\hline 35 & Yosia Marpaung & 68 & 80 & 75 & Tuntas \\
\hline Jumlah & $\mathbf{2 . 0 9 2}$ & $\mathbf{2 . 4 9 2}$ & $\mathbf{2 . 8 3 5}$ & \\
\hline Jumlah Siswa yang Tuntas & $\mathbf{8}$ & $\mathbf{1 6}$ & $\mathbf{3 1}$ & \\
\hline Jumlah Siswa yang Tidak Tuntas & $\mathbf{2 7}$ & $\mathbf{1 9}$ & $\mathbf{4}$ & \\
\hline Nilai rata-rata & $\mathbf{5 9 . 7 7}$ & $\mathbf{7 1 . 2 0}$ & $\mathbf{8 1 . 0 0}$ & \\
\hline
\end{tabular}

Dari tabel di atas dapat dilihat siswa yang tuntas hasil belajar pada pretes terdapat 8 orang siswa $(22.8 \%)$ dan siswa yang tidak tuntas hasil belajar sebanyak 27 oarang siswa $(77.14 \%)$ nilai rata-ratanya adalah 59.77. Pada postes siklus I terdapat 19 orang siswa $(54.28 \%)$ nilai rataratanya adalah 71.20. Pada postes silkus II diperoleh hasil belajar siswa dari 35 orang jumlah siswa terdapat sebanyak 31 orang siswa yang tuntas $(88.57 \%)$ sedangkan yang tidak tuntas hasil belajarnya sebanyak 4 orang siswa $(11.42 \%)$ nilai rata-rata 81.00. Untuk lebih jelasnya tentang peningkatan hasil belajar siswa dari postes siklus I, sampai dengan postes siklus II dapat dilihat pada tabel dibawah ini:

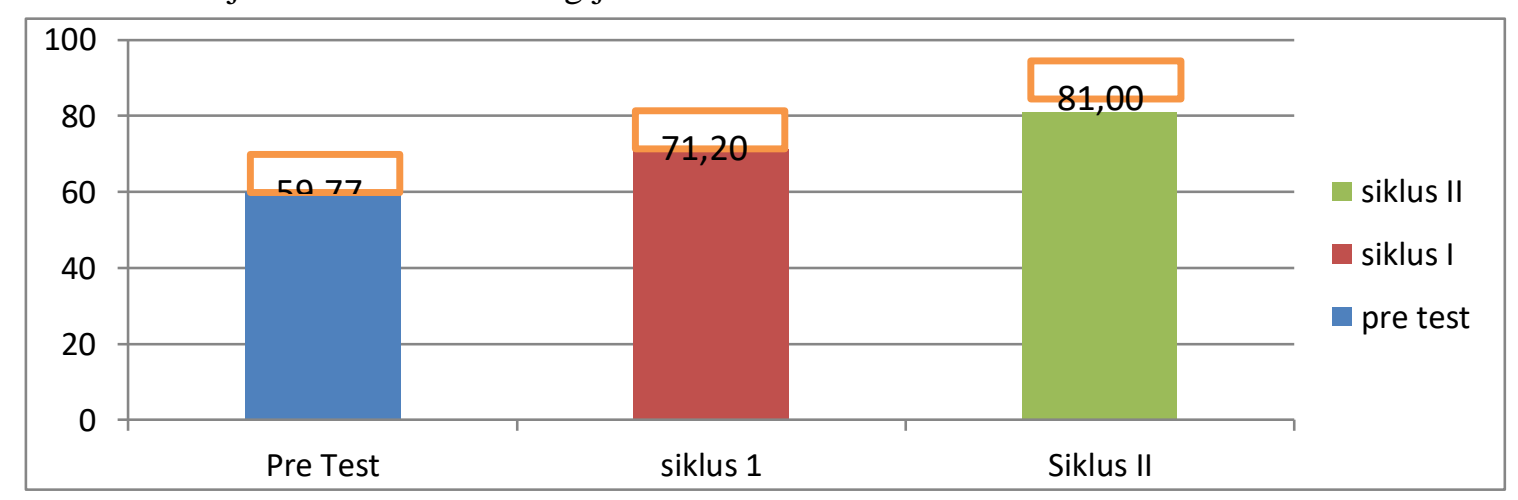

Gambar 2. Peningkatan Hasil Belajar Siswa Pada Pretest, Siklus I, dan Siklus II

\section{Perbandingan Hasil Belajar Klasikal}

Setelah diagram hasil ketuntasan belajar siswa secara individual, maka selanjutnya diperoleh hasil belajar siswa secara klasial dapat dilihat pada tabel dibawah ini. 


\section{PRIMARY: JURNAL PENDIDIKAN GURU SEKOLAH DASAR \\ VOLUME 10 NOMOR 6 DESEMBER 2021 \\ ISSN : 2303-1514 | E-ISSN : 2598-5949 \\ DOI : http://dx.doi.org/10.33578/jpfkip.v10i6.8549 \\ https://primary.ejournal.unri.ac.id/index.php/JPFKIP}

Tabel 4. Perbandingan Hasil Belajar Klasikal

\begin{tabular}{|l|l|l|l|l|}
\hline \multirow{2}{*}{ No } & \multicolumn{3}{|l|}{ Nilai Tes } & Keterangan \\
\cline { 2 - 5 } & Pretes & Siklus I & Siklus II & \\
\hline 1 & $22.8 \%$ & $45.71 \%$ & $88.57 \%$ & Meningkat \\
\hline Untuk lebih jelas mengenai
\end{tabular}

perbandingan tersebut dapat dilihat pada grafik

dibawah ini.

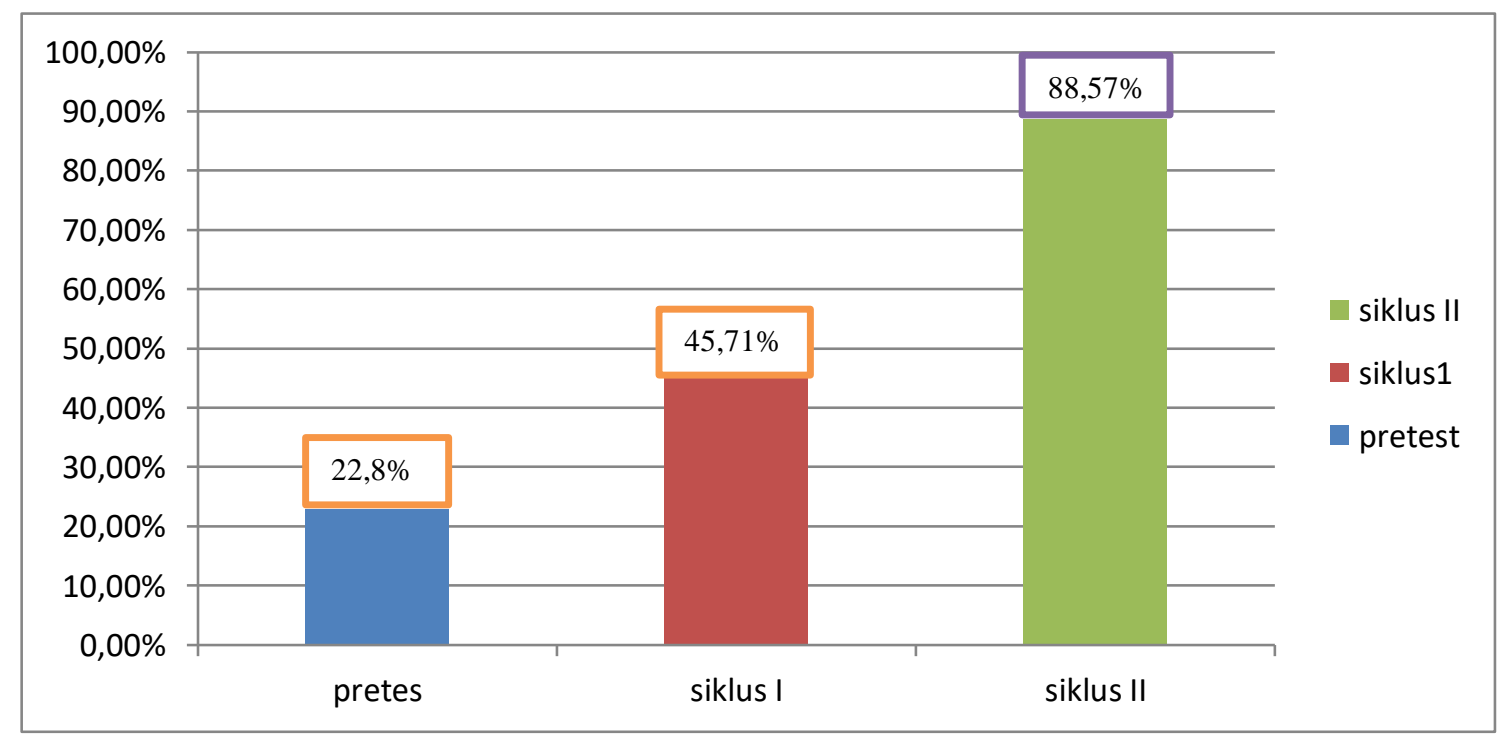

Gambar 3. Diagram Perbandingan Hasil Belajar

Dari tabel dan diagram diatas dapat dilihat bahwa terjadi peningkatan hasiil belajar klasial siswa. Pada pretes hasil belajar $22.8 \%$, pada siklus I sebesar $45.71 \%$, sedangkan siklus II sebesar $88.57 \%$. Hal ini menunjukkan bahwa ketuntasan belajar yang diharapkan secara klasial yaitu $88.57 \%$ sudah tercapai.

Perbandingan Hasil Rata-rata Siswa

Untuk mengetahui berhasil tidaknya tindakan yang dilakukan dalam penelitian sesuai dengan tujuan penelitian, maka dicari juga nilai rata-rata didalam kelas pada siklus I dan siklus II pada tabel dibah ini.

Tabel 5. Perbandingan Nilai Rata-Rata Siswa

\begin{tabular}{|c|c|c|c|c|}
\hline \multirow{2}{*}{ No } & \multicolumn{3}{|c|}{ Nilai Tes } & \multirow{2}{*}{ Keterangan } \\
\cline { 2 - 4 } & Pretes & Siklus I & Siklus II & \\
\hline 1 & $59.77 \%$ & $71.20 \%$ & $81.00 \%$ & Meningkat \\
\hline
\end{tabular}

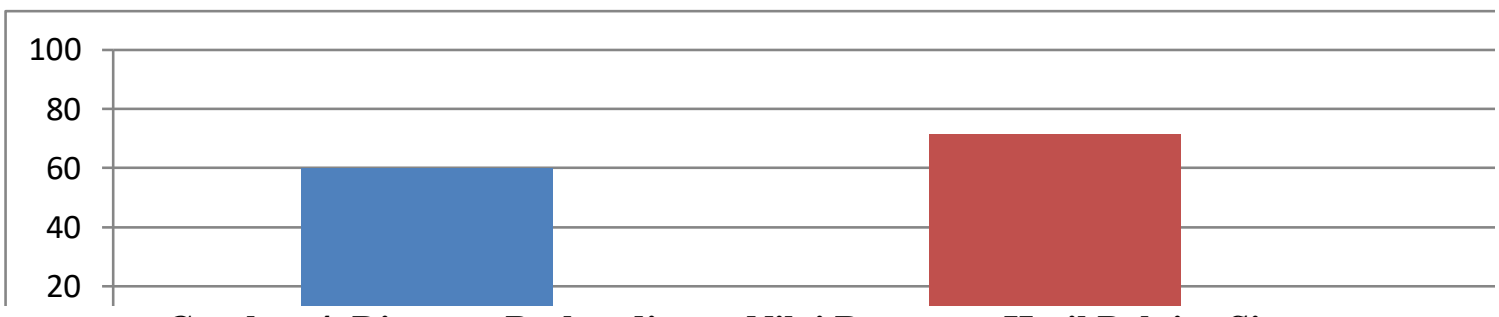

Gambar 4. Diagram Perbandingan Nilai Rata-rata Hasil Belajar Siswa 
Dari tabel dan diagram diatas dapat dilihat bahwa terjadi peningkatan hasil belajar klasial siswa. Pada pretes hasil belajar 59.77\%, siklus I terjadi peningkatan sebesar $71.20 \%$ dan pada siklus II juga terjadi peningkatan sebesar 81.00\%. Hal ini membuktikan bahwa dengan menggunakan Model Role Playing dapat meningkatkan hasil belajar siswa.

\section{Perbandingan Hasil Tindakan Aktivitas Siswa} antar Siklus
Berdasarkan data yang diperoleh dari observasi aktivitas siswa pada siklus I dan siklus II dapat dilihat adanya peningkatan. Dimana pada siklus I hasil observasi aktivitas siswa diperoleh sebanyak $62 \%$ kriteria baik dan pada siklus II meningkat menjadi $90 \%$ kriteria sangat baik. Berdasarkan peningkatan kedua siklus dapat dilihat bahwa siklus I dan II meningkat. Untuklebih jelas mengenai peningkatan observasi siswa dapat dilihat pada gambar diagram dibawah ini.

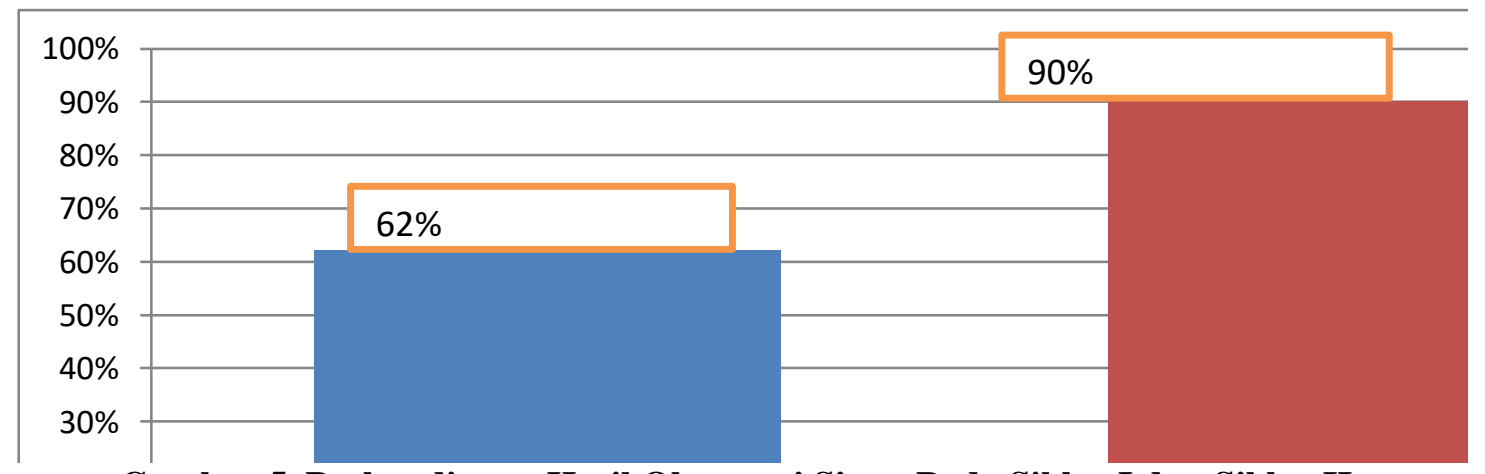

Gambar 5. Perbandingan Hasil Observasi Siswa Pada Siklus I dan Siklus II

\section{Pengujian Hipotesis Tindakan}

Dari pembahasan data yang telah diperoleh dapat dilihat bahwa terdapat peningkatan hasil belajar yang baik dari siklus I ke siklus II. Penelitian ini dikatakan berhasil apabila ketuntasan hasil belajar siswa secara klasial mencapai $71,40 \%$ dan pada siklus II diperoleh ketuntasan hasil belajar secara klasial sebesar $81,00 \%$. Jadi dapat disimpulkan bahwa melalui temuan yang telah diperoleh dapat memberikan jawaban terhadap hipotesis tindakan yang telah ditemukan sebelumnya bahwa dengan menggunakan Model Role Playing terjadi peningkatan hasil belajar siswa pada Tema Daerah Tempat Tinggalku di kelas IV SD Swasta Adven Timbang Deli.

\section{SIMPULAN DAN REKOMENDASI}

Berdasarkan hasil penelitian yan dilakukan oleh peneliti dengan Model pembelajaran Role Playing dapat meningkatkan hasil belajar siswa pada tema daerah tempat tinggalku kelas IV SD Swasta Adven Timbang
Deli Tahun pembelajaran 2020/2021, maka dapat disimpulkan sebagai berikut:

1. Dengan menerapkan Model pembelajaran Role Playing pada tema daerah tempat tinggalku, dapat meningkatkan hasil belajar siswa dan sudah memenuhi kriteria ketuntasan minimal (KKM) yang telah ditetapkan oleh sekolah yaitu 70. Hal ini dapat dilihat dari persentase ketuntasan belajar individu , klasikal, dan nilai rata-rata siswa yaitu ; pada pretes siswa secara individual yaitu 8 orang yang tuntas, secara klasikal yaitu $22.8 \%$ dengan nilai rata-rata 59.77. Pada siklus I secara individual yaitu 16 orang yang tutas, secara klasikal $45.71 \%$ yang tuntas dengan rata-rata 71.20. Pada siklus II secara individual yaitu 31 orang yang tuntas, secara klasikal $88.57 \%$ dengan rata-rata 81.00

2. Pelaksanaan pembelajaran dengan Model pembelajaran Role Playing pada tema daerah tempat tinggalku di kelas IV SD Swasta Adven Timbang Deli. Pembelajaran 2020/2021 dikategorikan sudah baik. Hal ini dapat dilihat dari hasil observasi aktivitas 
guru pada siklus I sebesar $66 \%$ dan pada siklus II meningkat menjadi $86 \%$.

3. Pelaksanaan pembelajaran dengan Model pembelajaran Role Playing di kelas IV SD Swasta Adven Timbang Deli pada tema daerah tempat tinggalku dikategorikan sudah baik. Hal ini dapat dilihat dari hasil aktivitas observasi siswa pada siklus I sebesar $62 \%$ dan pada siklus II meningkat menjadi $90 \%$.

\section{DAFTAR PUSTAKA}

Akbar, S., A'yun, I. Q., Satriyani, F. Y., Widodo, W., Paranimmita, R., \& Ferisa, D. (2017). Implementasi Pembelajaran Tematik Di Sekolah Dasar (Ke 2). PT Remaja Rosdakarya.

Arikunto, S. (2016). Dasar-dasar Evaluasi Pendidikan. Jakarta: Bumi Aksara.

Aqib, Z., \& Dkk. (2016). Penelitian Tindakan Kelas untuk guru SD, SLB, Dan TK. Bandung:YramaWidya.

Buaton, R. A., Sitepu, A., \& Tanjung, D. S. (2021). Pengaruh Model Pembelajaran Kooperatif Tipe Group Investigation terhadap Hasil Belajar Siswa pada Pembelajaran Tematik di Sekolah Dasar. EDUKATIF : JURNAL ILMU PENDIDIKAN, 3(6), 4066-4074.

Girsang, P. D., Tanjung, D. S., \& Azelina, D. (2021). The Effect of Group Investigation Type Cooperative Learning Model on Students' Learning Outcomes on The Themes of Daerah Tempat Tinggalku at Grade IV SDN 094117 Bangun Saribu. 5(20), 252-261.

Istarani. (2019). 58 Model Pembelajaran Inovatif. Media persada.

Karo, T. B., Anzelina, D., Sembiring, N., \& Tanjung, D. S. (2021). Meningkatkan Hasil Belajar Siswa dengan Menggunakan Model Spider Webbed pada Pembelajaran Tematik. EDUKATIF: JURNAL ILMU PENDIDIKAN, 3(4), 2108-2117.

Khairani. (2017). Pengaruh Tata Ruang Kelas Terhadap Perilaku Belajar Siswa Di Pekanbaru: 21.

Naibaho, D. E., Sipayung, R., \& Tanjung, D. S.
(2020). Hubungan Disiplin Belajar Dengan Hasil Belajar Siswa Pada Mata Pelajaran Matematika Kelas V Di Sd Negeri 24 Tanjung Bunga. School Education Journal Pgsd Fip Unimed, 10(4), 342-351.

Nainggolan, M., Tanjung, D. S., \& Simarmata, E. J. (2021). Pengaruh Model Pembelajaran S AVI terhadap Hasil Belajar Matematika Siswa di Sekolah Dasar. Jurnal Basicedu, 5(4), 2617-2625.

Ningrum. (2020). Penerapan Model Role Playing Untuk Meningkatkan Hasil Belajar SIswa Kelas V SD Negeri 2 kotagajah Lampung Tengah: 26.

Pardosi, B., Tanjung, D. S., \& Anzelina, D. (2020). Pengaruh Model SAVI terhadap Hasil Belajar pada Tema Organ Gerak Hewan dan Manusia di Kelas V SD Negeri 173593 Parsoburan. ESJ (Elementary School Journal), 10(3), 175-184.

Pulungan, I. (2019). Ensiklopedia Pendidikan (2nd ed.). Media Persada.

Purba, F. B., Tanjung, D. S., \& Gaol, R. L. (2021). The Effect Of Paikem Approach On Students' Learning Outcomes on The Theme of Lingkungan Sahabat Kita At Grade V SD Harapan Baru Medan Academic Year 2019/2020. Jurnal PAJAR (Pendidikan Dan Pengajaran), 5(2), 278-286.

Purba, J. M., Sinaga, R., \& Tanjung, D. S. (2020).

Pengaruh Model Pembelajaran Tipe Kooperatif Tipe Scramble terhadap Hasil Belajar Siswa pada Tema Daerah Tempat Tinggalku Kelas IV. ESJ (Elementary School Journal), 10(4), 216-224.

Rizkiah. (2019). Implementasi PembelajaranTematik Dengan Menggunakan Pendekatan Saintifik Kelas IV di SDN 4 Panarung Palangka Raya: 20.

Sanjaya, W. (2016). Penelitian Tindakan Kelas. Jakarta: Kencana Perdana Media.

Saragih, L. M., Tanjung, D. S., \& Anzelina, D. (2021). Pengaruh Model Pembelajaran Open Ended t erhadap Hasil Belajar Siswa pada 
Pembelajaran Tematik. Jurnal Basicedu, 5(4), 2644-2652.

Sembiring, S. B., Tanjung, D. S., \& Juliana. (2021). Pengaruh Model Pembelajaran Example Non Example terhadap Hasil Belajar Siswa pada Pembelajaran Tematik di Sekolah Dasar. EDUKATIF: JURNAL ILMU PENDIDIKAN, 3(6), 4075-4082.

shoimin. (2019). 68 Model Pembelajaran Inovatif dalam Kurikulum 2013 (R. KR (ed.)). AR.RUZZ.MEDIA.

Simorangkir, F. M. A., \& Tanjung, D. S. (2019a). ANALISIS PELAKSANAAN PEMBELAJARAN TEMATIK DENGAN PENDEKATAN MULTIPLE INTELLIGENCESBERBASIS BUDAYA BATAK ANGKOLA UNTUK SISWA KELAS IV SEKOLAH DASAR. Jurnal Education and Development, 7(4), 302-304.

Simorangkir, F. M. A., \& Tanjung, D. S. (2019b). Implementation of Multiple Intelligences Approach Based On Batak Angkola Culture in Learning Thematic For Class IV SD Negeri 100620 Pargarutan Julu South Tapanuli District. Budapest International Research and Critics in Linguistics and Education (BirLE) Journal, 2(4), 547-551. https://doi.org/10.33258/birle.v2i4.538

Sihombing, S., Sipayung, R., \& Tanjung, D. S. (2020). Pengaruh Perhatian Orangtua Terhadap Hasil Belajar Siswa Pada Mata Pelajaran Matematika Di Kelas Iv Sd Negeri 097350 Parbutaran Simalungun. School Education Journal Pgsd Fip Unimed, 10(4), 314-322.

Sinaga, R., \& Tanjung, D. S. (2019). Efektifitas Penggunaan Interactive Educational Multimedia Learning Berbasis Teori Kognitif terhadap Dyslexic Student di Sekolah Dasar. Jurnal Guru Kita, 3(4), 338341.
Slameto. (2019). Belajar dan Faktor-faktor yang mempengaruhi. RINEKA CIPTA.

Tampubolon, S. (2014). Penelitian Tindakan Kelas Sebagai Pengembangan Profesi Pendidik Dan Keilmuan. Jakarta: Penerbit Erlangga.

Tanjung. 2016. Meningkatkan Hasil Belajar Ips Siswa Dengan Menerapkan Model Pembelajaran Kooperatif Tipe Team Games Tournament (Tgt) Di Kelas V Sdn 200111 Padangsidimpuan. Juril AMIK MBP, IV(1), 73.

Tarigan, A. P., Tanjung, D. S., \& Anzelina, D. (2020). PENGARUH METODE PEMBELAJARAN SQ3R TERHADAP HASIL BELAJAR SISWA PADA TEMA INDAHNYA KEBERSAMAAN KELAS IV SDN 040549 PEBULAN. Jurnal Handayani, 11(2), 1-10.

Tarigan, E. B., Simarmata, E. J., Abi, A. R., \& Tanjung, D. S. (2021). Peningkatan Hasil Belajar Siswa dengan Menggunakan Model Problem Based Learning pada Pembelajaran Tematik. EDUKATIF: JURNAL ILMU PENDIDIKAN, 3(4), 2294-2304.

T.Dewi, I.Tegeh, I.Saurjana. 2017. Pengaruh Model Pembelajaran Kooperatif Tipe Role Playing Terhadap Hasil Belajar IPS Siswa Kelas V Gugus III Kecamatan Seririt Tahun Pembelajaran 2016/2017: 03.

Wahyuni. 2019. "No Title." Upaya Meningkatkan Hasil Belajar Siswa Pada Mata Pembelajaran PKN Materi Kebebasan Berorganisasi Melalui Model Pembelajaran Role Playing di KelasV MIN 4 Kota Medan: 41 